\title{
The Good Society: A Guide to Economic Policy
}

\section{Peter Kenyon}

I $\mathrm{n}$ the 1960s and 1970s students flocked to the universities to study economics. An economics training was thought to be a way to achieve a more civilised society - one where scarce resources are used more efficiently and one which is fairer in its treatment of all people, no matter where they live and no matter what their social class. In particular, economists were believed to have the solution to the problem of mass unemployment and all the waste, misery and inequity to which business cycle depressions give rise.

Upon graduation, neophyte economists of the Woodstock generation readily found employment. Honours and graduate training in economics was especially sought after. There was a widespread belief that the tools necessary to understand and change society for the better could be found in the tradition that ran from Smith through Keynes to Samuelson.

From 1945 to the Age of Aquarius, the world seemed to give some credence to this enthusiasm. Widespread unemployment, at least in the industrialised economies, seemed to be a thing of the past. Economic growth was palpable across much of the industrialised world and was slowly, if painfully, becoming evident in the so-called developing world, albeit mostly in Asia. Progressive taxation and the spread of the welfare state, which delivered or promised to deliver near universal basic education, universal basic health care and an economic safety net against the vagaries of the capitalist system, seemed to hold the promise of a fairer, more civilised world.

Economists were regarded as the gurus who understood these matters and could administer policy on behalf of the state in these endeavours. Economists very quickly rose to positions of power and influence in Canberra (Pusey, 1991). This phenomenon was not limited to Australia. Across much of the industrialised world, economists were appointed to positions of power and prestige, especially in the major domestic economic and social policy bureaucracies of the public sector. Economics and employment for economists boomed.

However, it is rather embarrassing these days to announce to a gathering of people that one is an economist. Economics has now become a dirty word in the minds of many. Indeed, in Australia it has been given the pejorative sobriquet 'economic rationalism.' To be an economic rationalist is not socially desirable. And the flood of students to economics courses, if not dried up, has substantially eased (Lewis and Norris, 1997).

Peter Kenyon is Professor of Economics and Director of the Institute for Research into International Competitiveness at Curtin University of Technology. 
Rather than being seen as the intellectual route to knowledge about how to contribute to a better and fairer world, economics, or at least that branch of it known as economic rationalism or neo-liberalism, is seen as a mean-spirited and ill-directed policy program that has infected both the public and private sectors. It has led, so its critics argue, to among other things:

- widespread job loss, particularly in the public sector, but significantly in the private sector as well;

- the inability of the economy to absorb all new entrants to the labour market, particularly the young and those with lower levels of skills;

- very high unemployment and, in particular, to entrenched long term unemployment;

- the decimation of the manufacturing sector;

- greater inequality both in terms of income and opportunity;

- the widespread loss of services, particularly consumer banking services and government services;

- the imposition of charges for services from both the public and private sectors, which were once available for free;

- a greater degree of economic uncertainty, particularly in respect of employment and income maintenance;

- a harsher and less humane industrial relations environment;

- and in the case of many rural communities, the loss of the minimum necessary level of business and government services to keep these communities economically viable.

Critics are partially correct in their assessment of the state of much of economics as it is practised in business, government and in some parts of academia. By and large, the economic rationalists are in the ascendancy and the consequences are often neither efficient nor equitable, despite the promise.

However, as inadequate as many of these consequences are, it is also important to recognise that much good has come out of the neo-liberal economic agenda too. The critics should also recognise the benefits that have flowed from this agenda. A partial list includes:

- cheaper and wider access to a vast range of imported goods and services (for example, clothing, motor vehicles, electronic products);

- greater competition and therefore lower prices and more variety in many markets;

- vastly cheaper telecommunications, air travel and computer technology;

- easier and largely non-discriminatory access to cheaper credit (increased bank charges notwithstanding);

- more transparent access to government contracts;

- more transparent and often cheaper access to infrastructure, and

- longer shopping hours, at least in the capital cities. 
The purpose of this article is not to denigrate the neo-liberal economic policy agenda as being wrong. Rather the argument is that this agenda is, in fact, poor economics. It is poor because it is incomplete. This selective use of economics is what constitutes economic rationalism or neo-liberalism. Economic liberalism as it has often been practised in government as policy is ideologically selective in what it takes out of the economics tool-kit. As a result, it has neglected some extremely important economic theory and empirical knowledge which, if included in the policy agenda, would have delivered a far better and more civilised outcome over the last twenty or so years. Before embarking upon this argument, however, it is necessary to make some observations about the application of economic theory to economic policy.

\section{Economic Theory and Economic Policy}

It is very important when applying economic theory to actual economies as economic policy to be absolutely clear as to what is always true under all circumstances, what is true under restrictive assumptions and what is a matter of empirical judgement and thus dependent upon time and circumstance. All too often, these distinctions are not made by economic commentators and, more importantly, economic policy advisers and decision makers.

Very little of economic theory meets the first criterion - it is always true under all circumstances. Are tariffs are always welfare reducing? Is free trade always the best policy, no matter what? Obviously the complete, as opposed to the ideologically selective economist would have to firmly answer, 'No!' There is just too much economic theory that allows trade protection to be welfare enhancing under certain (restrictive) circumstances (Dixit and Kyle, 1985). Do minimum wages always reduce employment? Again, the complete economist would have to answer 'No!' There is just too much empirical evidence to the contrary (Card and Krueger, 1994). Many very basic theorems are subject to qualification and judgement when applied to actual economies.

Things become even more a matter of judgement when we consider the extent to which, for example, government should tax or borrow in order spend on public works, education, health. Or the extent to which financial markets should be regulated. Or the extent to which consumer protection laws are necessary. Or the extent to which the environment should be protected against commercial development and overuse, and so on.

Indeed, the complete economist recognises that nearly all of public policy in the economic sphere is a matter of judgement. As Geoff Harcourt, distinguished Australian economist and trenchant critic of neo-liberal economic policy, argues, a good understanding of both economic theory and economic policy requires the policy practitioner to make judgements about 'horses for courses.' Virtually nothing in economics, when applied to policy, is a matter of absolute truth. Perhaps demand curves always slope downwards. (But the complete economist as 
policy practitioner knows all too well about the importance of the elasticity of demand.)

What is sketched out here is a guide to the 'Good Society,' one that draws on a more complete set of tools from the economist's toolkit than that currently fashionable under the economic rationalism/neo-liberalism agenda. This 'Good Society Guide' is necessarily based on personal judgement and preferences and no apology is made for that. How could it be otherwise? However, it is hoped that the judgements that are made are guided by a more complete economics than that used to guide much of public policy over the last two decades.

\section{The Market and the State}

At least since Adam Smith, economists and policy makers have had to come to grips with the optimal role of government in promoting economic welfare. On the one hand, economic theory, particularly neoclassical general equilibrium theory, shows that under fairly strict assumptions, a competitive equilibrium in a market economy will deliver a welfare maximum. That is, a market economy operating in the absence of any government economic intervention, save for the specification and protection of property rights, will deliver an allocation of resources such that no person can be made better off without some other person being made worse off.

This 'invisible hand theorem' is a powerful result, one which has influenced policy design significantly, and is the theoretical basis for economic liberalism. It has led to economists advising, in general, against tariffs and subsidies, against aiding specific sectors or industries, against assisting any factors to locate anywhere and, in general, against government regulatory interference in markets. It has led to policies to promote competition in all markets. Therefore policies should attempt to be neutral in their allocative effects. Taxes ought be designed as much as possible not to favour one group over another (save for explicit equity policy). Microeconomic policy should take the form essentially of creating initial conditions under which all firms, industries, factors and consumers can compete in the market place on an equal footing. These initial conditions are basically defining and enforcing property rights. This stance can be summed up by the popular economic rationalist slogan that the role of government is to "create a level playing field' such that the private sector can get on with its job of allocating resources efficiently through competitive markets.

The role of government in respect of macroeconomics is a little unclear in neoclassical general equilibrium theory, at least in its simplest form. This is because in the model exchange occurs essentially through barter. However, where money is added as a medium of exchange (which of, course, makes market exchange far more efficient), under quite restrictive conditions the introduction of money is 'neutral' in respect of the 'real' economy in 'the long run.' That is, monetary policy, controls the aggregate price level and so the only role of the central bank is to operate monetary policy in order to control inflation, as it cannot affect the level of activity or employment 'in the long run.' It is important to note 
that the key assumption that delivers this result essentially involves perfect foresight by all market participants.

What constitutes neo-liberal economic policy is difficult to ascertain for the ideas are broad and tend to change according to time and circumstance. However, certain key measures seem common to all countries that have adopted a liberal approach to economic policy over the last several decades.' These are:

1. The adoption of policies which lead to freer trade and the rejection of protectionist policy, broadly defined to include both tariff and non-tariff barriers.

2. The rejection of exchange controls and the freeing up of international capital movements. In some cases, like Australia's, this has meant the (virtually) free floating of the exchange rate and in others, more complex exchange rate regimes have been adopted, from pegging to a dominant currency to the adoption of common currency areas.

3. An approach to public finance which incorporates:

- reducing and eliminating fiscal deficits;

- limiting of the size of the public sector through the privatisation or corporatisation of government economic enterprises and the contracting out of non-core (and even core) services where appropriate;

- the mimicking of market processes in the purchasing and sale of goods and services by the public sector through such processes as competitive tendering, comparative benchmarking exercises, and the implementation of competition policy as it applies to government agencies;

- taxation reform that places more weight on indirect taxes (for example a consumption tax, like the GST) and less on direct taxes (such as income and corporate taxes); and

- a narrowing of universal 'safety net' welfare eligibility and a greater reliance on 'mutual obligation' - the exchange of economic contribution - as part of eligibility criteria.

4. The liberalization of labour markets to include greater reliance on markets in wage and employment determination and less reliance on institutional or regulatory agencies as parties to wage and salary agreements. Part of this move is a greater reliance on decentralized individual contracting and less reliance on collective bargaining.

5. The liberalization of goods and services markets to encourage greater competition through the adoption of policies which lead to a more competitive

1 For an excellent exegesis of economic liberalism from a supporter of its policy agenda, see Henderson (1995). 
ervironment. In Australia this has come about through the adoption and implementation of national competition policy.

Often these measures collectively come under the general rubric 'microeconomic reform.' While many if not all economists would agree with much of this policy agenda, most would wish to add critical caveats to the measures. The problem with much policy implementation over the last two decades is that the economic rationalist agenda has all too often neglected these necessary caveats.

The problem, of course, is that the assumptions needed to produce the laissezfaire results of general equilibrium economic theory do not match reality. First, the real world is subject to factors which are assumed away in the "invisible hand theorem.' There are a range of factors which lead to either market failure or which violate the conditions of perfectly competitive markets with perfect foresight. Market failure also opens the way for a theoretical rationale for government to intervene in the market economy in order to increase economic welfare. Importantly, the various forms of market failure often interact with one another, which makes the problem of private provision even more problematic. The major forms of market failure include:

\section{Public goods}

Due to characteristics such as non-excludability and non-rivalry in consumption, markets for certain goods and services are not well-defined because the consumer preferences for those goods and services are not revealed through market processes. Public parks and wilderness reserves, public art works and some public leisure facilities (bicycle tracks, walking tracks, and the like) have public goods characteristics, as does free to air TV and radio. Many publicly provided goods and services, from street lighting through to road systems fall, more or less, into this category because of the fact that there is 'market failure' in their provision by markets.

Public goods provide a prima facie case for government intervention through government provision. Because the social value of public goods cannot adequately be revealed though the market, it becomes the responsibility of the state to ascertain their value and to supply them to the public. It is important to emphasise the point that the social value of public goods cannot be ascertained through market processes and thus are, for the most part, a matter of judgement. All too often, agencies are required to attempt to 'value' public goods in order to justify their provision. This is extremely difficult. A case in point is active labour market programs. Often these involve the construction of local public goods, for example community facilities such as bicycle tracks and walk ways, public conveniences and the like or public services such as reversing environmental degradation. Yet critics routinely disparage such valuable social goods, as 'painting rocks white' because the critics cannot place a market value on the output of these schemes. 
The public goods characteristics of non-excludability and non-rivalry in consumption often interact with another major form of market failure, namely economies of scale. Many infrastructure projects, for example 'network systems,' such as electricity or water or gas distribution or telecommunications systems, come under this category and microeconomic policy that is cognisant of public goods will often see government involvement in the provision of physical and human capital infrastructure.

Of course, schemes for excludability can be derived which overcome some element of the public good nature of many of these public goods (for example, toll roads, timed telephone calls). Or the public good characteristic can be combined with some other private good characteristic to make private provision feasible (for example, advertising on TV and Radio). However, like much of economic policy, the complete economist will have to make a judgement about the social costs and benefits of removing the public good characteristic and turning the provision over to the private sector against leaving provision with the public sector.

\section{Externalities}

These are the unintended consequence of one economic agent's economic activity that affect another agent's economic activity, but which are not adequately priced through the market. Externalities may be beneficial or detrimental. For example, a firm producing as a by-product polluted water or air detrimentally affects other producers (or consumers) who require clean water or air in their economic activities (or their enjoyment). Of particular concern is the problem of natural resource depletion and environmental degradation. The social cost of these, much of which falls on future generations, are not adequately reflected in the market prices of goods and services. These reflect only private costs and benefits. There is a prima facie case for government intervention through regulation or taxation or subsidy provision to account for externality effects in order to prevent the overexploitation of these resources.

Beneficial externalities come about where the social benefits of an activity, part of which are not accounted for by market prices, are greater than private benefits. For example, if an infrastructure project, like a road or a port or a training facility is built, industry may be attracted to a location which otherwise would not have chosen that location. Or publicly provided research results in extensive development of industry so that more, better or cheaper goods and services become available. Often beneficial externalities lead to government policy intervention through subsidies and grants to assist in the creation of 'industry externalities' in the provision of physical and human capital and the encouragement of research and development.

\section{Information asymmetry}

Information asymmetry occurs when buyers and sellers cannot have access to the same information about details of transactions. Where agents do not have the same level of information, market-mediated exchanges will not necessarily be 
efficient. This is often the case in financial markets where potential investors cannot obtain accurate information about proposed investments. It may also be the case that new ventures cannot reveal to the capital market the potential value of their innovation and so cannot obtain the socially optimal level of financial capital to finance their operations. Information asymmetry is often the rationale for consumer protection policy, the prudential regulation of the finance sector, the regulation of industry standards, building codes, safety and occupational health standards and so on. It may also provide a rationale for 'start-up' assistance of various kinds.

\section{National and international economies of scale}

Economies of scale provide a fourth rationale for microeconomic policy that departs from simple laissez-faire. Economies of scale often lead to monopoly. For example, in many utilities, especially those that rely on extensive networks, such as energy or communications, falling unit costs relative to the size of the market as the network extends often mean that only one supplier can successfully remain in the market. This gives rise to government intervention either in the form of monopoly regulation (which may include regulation of access to networks, like rail or communications networks) or through government provision of goods and services which are provided by 'natural monopolies'. It should also be noted that economies of scale sometimes interact with externalities to provide another type of market failure. For example, the more people that are connected to a telephone or transport network, the greater is the benefit of that network to all who use it, thus providing an a priori justification for state intervention in its supply.

In the international sphere, economies of scale give rise to a role for activist industry policy through what has come to be known as strategic trade policy (Krugman, 1988). It has been shown that it is possible for a country to capture international monopoly rents from other countries by being able to establish industries subject to large economies of scale within its borders rather than allowing these industries to locate elsewhere. It is this area of 'new trade theory' which has provided the most recent justification for activist industry policy, but which has also been extremely controversial (see Krugman 1987, 1996).

\section{Macroeconomic equilibrium at less than full employment}

Unemployment is a reality of real world economies. Why this remains controversial sixty years on from Keynes' General Theory is an indication of the strength of the ideological appeal of the neoclassical paradigm. However, the complete economist would observe that business cycles are a fact of capitalist economies. Periodic variations in aggregate demand can and do cause sustained recessions and even depressions.

The paradoxical thing about this is that economists have more or less solved this problem. Yet policy makers are paralysed by inaction and allow preKeynesian polices to predominate (Krugman, 1998 and 1999). 
Why is this? The problem is that in the $1970 \mathrm{~s}$ and the early 1980s, macroeconomics suffered a crisis on two fronts. The first was on the policy front. Stagflation, the simultaneous problem of high and rising inflation and high and persistent unemployment, badly affected the credibility of what had become the 'Keynesian' policy package of countercyclical monetary and fiscal policy that had emerged from the uneasy settlement of the inconsistency between conventional microeconomics and 'Keynesian' macroeconomics. ${ }^{2}$ The settlement was not theoretical - purists continued to rail against the lack of 'microfoundations' of Keynesian macroeconomics. But as long as the policy advice which followed from Keynesian macroeconomics worked, the settlement held. For it allowed conventional neoclassical microceconomists to be able to offer conventional neoclassical microeconomic advice safe in the knowledge that one of the necessary conditions of such analysis - that there is full employment - is likely to occur. Conventional neoclassical microeconomic analysis depends on the presumed ability of governments to maintain more or less full employment.

Second, at the same time, and probably partly as a result of the inability of policy makers to deal with stagflation, Keynesian macroeconomics came under attack from within the ranks of economic theory. The rational expectations revolution challenged the whole idea that governments could successfully engage in countercyclical monetary and fiscal policy. This so-called 'new classical' macroeconomics stressed the importance of the fact that it was supposedly firmly rooted in conventional neoclassical microeconomics. It was theoretically elegant and was embraced by a sizable percentage of the profession, despite the fact that it did not ever provide an alternative plausible explanation for the instability of business cycles.

As a result, we have the curious situation where conventional wisdom regards 'Keynesian' macroeconomic polïcy as hopelessly simplistic and old fashioned while it embraces pre-Keynesian ideas of raising interest rates, cutting back on government expenditure and engaging in 'structural reform' to counter unemployment! ${ }^{3}$

\section{Efficiency and Economic Poliicy}

The 'Good Society' must deal with the problem of market failure, for a moment's thought will suggest that market failure in its various forms is endemic to capitalist economies. However, in the ecomomic rationalist policy agenda, market failure is essentially swept under the carpet as a minor irritant. The reason is entirely ideological. Market failure is a justification for state intervention to make the market economy run more efficiently. As long as the problem of 'government failure' can be addressed, the case for balanced and well-judged state intervention in the market economy to improve economic efficiency is very powerful. This is

\footnotetext{
2 Whether this followed chapter and verse from Keynes himself is irrelevant. The important part that is 'Keynesian' is that activist countercyclical monetary and fiscal policy could be used to counter bouts; of unemployment.

${ }^{3}$ Krugman (1999) addresses this problem in the context of the Asian crisis of 1997.
} 
an anathema to economic rationalists. Yet the complete economist has any amount of theoretical and empirical knowledge for a watertight case as to why such intervention is necessary.

First, the 'Good Society' will realise that it is essential for the state to provide an adequate supply of public goods, for by and large, they will not be provided by the private sector. It is a matter of judgement as to what constitutes an adequate supply of public goods. But this is the point. Under the simple economic rationalist view of the world, public goods are rarely mentioned, let alone taken seriously. There should be continuous examination of how living standards can be improved by the state supplying goods and services which meet, in some degree, the criteria of non-excludability and non-rivalry in consumption. For there is nothing surer than the proposition that the 'Good Society' will be one where the state is responsible for the comprehensive provision of educational and health services, leisure and sporting facilities, and substantial funding of the arts, such that these services are available to as many of its citizens as possible. It is the neglect of these goods and services in U.S. society that gave rise to the famous judgement of John Kenneth Galbraith (1958) that the U.S. was headed towards the imbalance of 'private affluence and public squalor.'

Second, the 'Good Society' will be very aware of the need for the scrupulous attention of the state to the problem of externalities, both negative and positive. Negative externalities, such as pollution, require the active role of government to regulate them, either through taxes and subsidies or direct regulation or the making of a market in the right to trade in permits. Different forms of externalities will require different solutions, so the 'Good Society' will see to it that the bureaus of the state charged with dealing with negative externalities will be sufficiently well-funded and sufficiently shielded from capture by industry (see below) that objective assessments of the value of these externalities can be made and appropriate public policy implemented.

In the case of positive externalities, the response will be different. Here the state can mobilise resources, both private and public, through taxes, subsidies and its own expenditure to put in place ways of capturing these externalities. To take but one example, there is a considerable literature on how factors external to each of the firms which comprise an industry (or part of an industry) but internal to the industry as a whole can create industry growth greater than what would occur in the absence of these external economies. Examples are where by providing infrastructure, both physical and educational, governments can conduct industry policy' which will enable the 'assisted' industry to grow larger and produce more efficiently than it would in the absence of the assistance. Similar arguments can be made about assistance with research and development. The CSIRO is but one example, in the Australian context, yet there are many others - for example, policies to create synergy between university research and industry through research grants and the like.

The 'Good Society' will be very aware of the opportunities presented by external economies to conduct activist 'industry policy' which is welfare enhancing. It will devote resources to seek out and exploit these opportunities. 
Yet, in the economic rationalistt policy agendi, activist industry policy is rejected as the futile attempt by government 'to pick vinners' and is rejected out of hand. This is a purely ideological position, and is not grounded in a more complete understanding of economic theory and evidene.

Information asymmetry iss pervasive in modern society. It is virtually impossible for all parties to complex business contracts to have equal access to technical and financial informattion. The 'Good Society' will recognise this and be assiduous in its attempts to protect its citizens from opportunistic behaviour by buyers and sellers with unequall access to information. It is essential that citizens, particularly when entering into contracts that out at risk a considerable proportion of their wealth, are protected from lack of information. This requires that the state ensures that there is extensive regulation to ensure full disclosure and as much transparency as possible about the terms and onditions of contracts, that technical standards are met, that qualifiedl practitioners perform the work, and so on. This is an essential part of competitiom policy, perhas even more important than issues about the competitive neutrality of government business enterprises that concern the economic rationalists so murch.

The 'Good Society' will allso be vary awre of the conditions which give rise to natural monopoly and every case will be carefully scrutinised on its merits. There is absolutely nothing in esconomic theory that suggests that a private natural monopoly is better than a public natural monopoly. Indeed, at least in the case of a public natural monopoly, the monopoly rens are returned to the state and have the possibility of doing some social good. Yet a good deal of the economic rationalist agenda seems to be about the privatisation of public natural monopolies. Upon privatisation, any monoply rents will be for the benefit of shareholders and management, and not the gereral public.

Finally, in terms of economic efficiency let alone equity - to which we will turn presently) the 'Good Societty' will be very aware of the cost of unemployment and the necessity to use the statte's expenditue and taxing capabilities to conduct countercyclical monetary and filscal policy todeal with unemployment. The cost of unemployment in Australia in terms of lost GDP that has come about as a result of the failure of policy to deal effectively withunemployment are huge.

Even under the most pessimistic (and amost certainly unrealistically low) estimates of the potential productivity of unenployed workers, the welfare losses due to unemployment are enormous. Australi at minimum has lost well over 1.5 per cent of GDP per year for the last twenty years because it has not implemented policies to generate full employment; indeed a welfare loss which averaged over 3 per cent of GDP every year for over 20 years is the more likely figure. Australia has essentially given away, at the least, one whole year's worth of its real GDP over the last two decades or so because it ias not been willing to implement policies which would have generated full empbyment (Kenyon, 1998).

It is most interesting to contrast this co:t with the benefits ascribed to the 'microeconomic reform' agenda (namely, Hilner and related reforms, as assessed by the Industry Commission, 1995), so der to the hearts and minds of the economic rationalists. It would not be an exaggeration to suggest that the 
microeconomic reform agenda has come to dominate economic policy in this country. The estimates of the welfre gains that would allegedly flow from the implementation of this microecononic reform agenda range from about 5.5 per cent of GDP (Industry Commission.1995) to at most about one per cent of GDP (Quiggin, 1997). Quiggin subjecs the assumptions and calculations of the Industry Commission (IC) estimatesto close scrutiny. His much lower estimate of the gains from the reform agenda esults from: his finding that most of the IC estimates of productivity gains thatwould comee from reform are overoptimistic due to the use of inappropriate benhmarks and inappropriate assumptions about productivity growth and therefore rpresent upper bounds rather than most likely outcomes. Further, he observes that many of the workers displaced from employment by the reform agenda vill not be entirely absorbed elsewhere in the economy in equivalent jobs, but it least some of them will be permanently displaced from employment and chers are alımost certainly moving into jobs which require fewer skills, both of which implly a semi-permanent shift in the effective supply of labour (Quiggin 1997). Wes should not lose sight of the fact that much of the reform agenda is abut reducing employment in the public sector.

In summary, it is apparent tha the gains in terms of additional GDP from microeconomic reform are at the nost comparable with the losses in GDP that have resulted from 25 years of liss than full employment and are probably considerably less in magnitude, yetmicroeconomic reform dominates the policy agenda. One might speculate on the welfare loss due to the macroeconomic intellectual vacuum in economics that has resultted from the demise of Keynesian economics as an operational stabilsation policy package. The reason why the problem is difficult is that the soluion is a pollitical decision about faimess and equity as much as it is an economic lecision about economic efficiency.

\section{Equity and Economic Policy}

A 'Good Society' is one where the naterial gap between the wealthy and the less fortunate is not too great. Just what the ratio should be is a matter of judgement - again there are no clear answers. However, where the gap is too large, history reveals that social dislocation and eren unrest imcreases and that the likelihood of peaceful economic progress declines as the gap widens.

Economic theory suggests that there is no such thing as an optimal distribution of wealth or income. Indeed, one of the important features of the neoclassical general equilibrium nodel is that its basic result that a market economy will deliver a welfare maximum in the sense that no one can be made better off without someone being nade worse: off is independent of the initial distribution of wealth (Bator, 1957). This is not to say that in this model everyone ends up in the same economic ituation, no matter where they start from. Different starting endowments are likely to lead to different wealth end points, too.

Rather, the theorem says that it does not matter what the initial distribution of endowments is in order to get to a competitive equilibrium, whereby prices of 
goods and services reflect the (priivate) opporunity cost of the resources that go into their production. So, if it doestn't matter what the initial distribution of wealth is, what would the 'Good Society' cchoose in respect of wealth distribution?

There is no easy answer to this problem. It is one philosophers have been grappling with for a very long timee. However, one answer is very appealing and that is the one suggested by the U..S. philosopier, John Rawls, in the second half of the twentieth century. Rawls arrgues that even self interest is likely to lead to the choice of a more rather than lesss egalitarian society.

His argument is very complex;, but essentally rests on what we would choose as a wealth distribution if we did mot know before we made the choice where we would end up after the choice was; made. Rawls argues that we would choose an egalitarian society out of self interrest, simply because under such a distribution, we would not run the risk of endimg up on the poor tail of what might be a very unequal distribution. Thus he shorws that we do not even need value judgements or a moral sense for egalitarianismı to be a feature of the 'Good Society' ${ }^{4}$ To the extent to which values and morality add to the choice of a more equal society, so be it. Of course, since Rawls; advanced this proposition any number of philosophers and economists have found special cases and conundrums which weaken the basic idea. Neverthelless, Rawls' theory of justice remains a good guide to thinking about distributional issues.

Now comes the tricky bit. So far the argument has been about some arbitrary initial allocation of wealth, unrelatted to economic decisions to allocate resources, including labour resources, to different forms of economic activity. Of course, short of hereditary wealth, this is not the major issue about distributional issues. Neoclassical economic theory argues that prices are the signals by which people make decisions to allocate resources and thus these decisions will determine the income that people receive from their command over resources (including their own labour resources). Wealth is simply the accumulation of net income. So incentives about wealth accumulation matter in order to achieve an efficient allocation of resources.

The complete economist mustt, of course, recognise this fundamental insight about the nature of a market economy. However, neoclassical general equilibrium theory also suggests that non-distontionary transfers to redistribute income will not affect economic efficiency, so thatt income distribution is ultimately a matter of social choice. Thus the design of taxation and welfare systems must be such as to create as few as possible economic distortions that create perverse incentives (for example, very high marginal tax rates or welfare payment systems which make further work unattractive, to the point of withdrawal from the labour market).

But the complete economisit is also aware that the responsiveness of behaviour to price signals (elasticities in the economist's jargon) differs greatly between different types of economic behaviour. Empirical evidence seems to

4 Indeed, Rawls' theory of justice is even more favourable to egalitarianism than this would suggest in that his 'difference' principle would require policy to favour the least disadvantaged in society. 
suggest that at the level where theynatter for inccome distribution policy - at the extremes of the income distribution - the elasticities are very small.

Consider the most important ad of the inccome distribution first, the lower income tail. It is often argued b ideologicallly driven economists and policy makers that such safety net featuresof the 'Good Society' as minimum wages and unemployment and other welfare enefits mustt be kept to a minimum because they may interfere with the incentie to work. IFor the greater majority of people who find themselves in need of thesocial safety net, the desire to increase access to basic material goods is more tha sufficient to motivate the incentive to work. Welfare benefits or minimum wags are rarely' a barrier to the natural desire of humans to improve the material coditions of their lives. To deny this is to deny the obvious fact that in good timeswhen labour demand is high, unemployment can get to very low levels and labar force partticipation actually tends to rise as the likelihood of employment inceases. To argue otherwise is to argue that Australians in the $1950 \mathrm{~s}$ and $960 \mathrm{~s}$ were psychologically different from Australians today in terms of the motivation to work and to improve their standard of living.

This is not to say that welfaresystems will always operate perfectly. There will always be in the cases where ertain indiviiduals will be motivated to exploit the welfare system and shirk. Howver, the factss are that the numbers are so small as to be irrelevant in the 'Good 'ociety.' From the point of view of civilised policy making which creates socialsafety nets tto prevent poverty, the very small number of people who exploit the relfare system is a small price to pay to protect the many.

Turning to the other end of th income distribution, it is difficult to see how the vast sums of money that ccporations awward their senior executives as recompense for their efforts are neessary to eliccit that effort. The 'Good Society' should scrutinise very closely vev high incoimes and ensure that those lucky enough to obtain such incomes paytheir fair share of taxation and so contribute to the betterment of society as well ashemselves.

Again there is no clear guide is to what a perfect tax system is (if ever one existed). However, it is essential tat the state :is able to raise enough revenue in order to be able to carry out its essatial functioms. It would appear, though, that a simple progressive tax system is a ecessary part of the 'Good Society.'

\section{Government}

The 'Good Society' needs good government. As we have seen, economic theory allows for a significant role for the tate. So, we must address head on the issue of how does the 'Good Society' ensue that the sttate operates in the public interest. There are three issues.

The first is an age-old problen that exists with any large organisation, public or private. It is that as organisatios become larger, hierarchy and rules become more important in order to maintair discipline and order - in essence to allow the organisation to operate at all, let alone effectively. Whereas, in small 
organisations there is ample scope for the cganisation to operate through the intuition and caprice of one personı or a small tam of people, often in exciting and truly productive ways, this is impossible as organisations grow. Bureaucracy takes over from intuition and indiwidual actior. The problem is that this can then lead to the mindless applicationı of bureauratic procedures without thought, without the necessary consideration that perlaps the environment has changed, that the rules - 'the way things : are done' - have been superseded by events. Much dissatisfaction with the appraratus of gevernment, from Parliament and the political parties, through the burezaucracy anc even the legal system rests on a perception of inefficiency that stems from the nability of these organs of the state to flexibly respond to individuals" needs. Tle inefficiency of the state is often thought not to arise from opportumistic behavour but rather from inertia and the inability of its agents to adequately/ reflect the eal needs of citizens.

As indicated, bureaucratic sclierosis is notlimited to the public sector. Large private sector organisations can sulffer from ths syndrome, too - think of IBM or General Motors or BHP. Howeverr, the markerdeals with this in the private sector by simply stopping the provision of capital toinefficient firms. The process may be slow and painful - and often 1 the first reponse of sclerotic firms is to shed employees, many of whom may not be part of the problem (one reason why the state must be concerned with unifair dismisal). Nevertheless, the problem is eventually solved - either the organisation barns and adapts, or it goes out of business. In the public sector, there is not ths discipline, so the 'Good Society' must have in place mechanisms for dealing wih bureaucratic sclerosis.

The second issue is opportuniistic behaviqur by the people who make up the organs of the state. Public choice theory has derted us to the possibility that it is naive to suppose that the state always operatesin the public interest, that its agents are not seduced into giving private interests nore weight than the public interest when making judgements about public policy. There are any number of examples of 'capture' of state regulatory and policy auhorities by the private interests of specific industrial sectors or sectional intersts. At its worst, opportunistic behaviour by state employees can degenerate ito corruption. However, there is a milder, but possibly more pervasiive problem and that is it is always easier to solve a problem where there are conflicting needs by spending money. It is even easier when it is other people's money! Prirate interest might override public interest simply because the line of least resstance is to give in to competing demands through expenditure of public funds. Therefore, the 'Good Society' must be aware of this inherent weakness; in the state and guard against it.

The third issue is related to the second. $I$ is that in any organisation, there is an inherent tendency for it to grow. First, it is obvious that work is always easier if the load is spread over more pecople. If it is possible to hire more people, they will be hired. Second, individualls gain inflence and prestige through empire building. Big departments tend to lbe importan departments. Often the prestige of an individual is measured by the number of people that are under his or her control. This is not necessarily a bad thing. Good managers have to be able to manage large numbers of people, sso it is not atogether unreasonable to reward the 
managers of large departments wth prestige and higher levels of influence. Nevertheless, it is not beyond the bunds of reassonableness to suppose that empire building is an inherent problem of rganisationss, and especially the public sector where the discipline of the marketis not presernt to stamp out inefficient empire building. So, the 'Good Society' nust find wayys of ensuring that the state does not become overblown with inefficint empires.

There are no easy answers tothese problems with Government. However, several observations can be made. It is important to realise that if the state is to work efficiently and in the public interest, then its employees must be paid well. The competition for talent is vry strong, and if public sector pay falls significantly behind private sector ay then perfformance in the public sector will necessarily fall. There is absolutly no case in economics to believe that the public sector can somehow surviv on a signifficantly different pay scale to the private sector. The 'Good Societ' recognises this and pays its public sector employees sufficiently well to attrart the best tallent suited to public service.

However, it is not only pecunary rewards: which attract talented individuals into the public sector. Influence ind the intellectual demands of public policy formulation and advice have their rewards as; well. The 'Good Society' will recognise this and ensure that condtions in the public sector, especially at senior levels, are such that the proffering of well-thought through policy advice, without fear or favour, is rewarded and erouraged. A professional civil service which encourages and rewards independett thought iss vital as a defence against private interests dominating public interet in the formulation and implementation of public policy.

This may require contractud conditions in the public sector to differ significantly from those in the privite sector. Im particular, limited term contracts, especially those whose terms match the prolitical electoral cycle, may be completely at odds with this vital role that the public service should and must provide. The 'Good Society' and the complete economist will realise that a more efficient public sector that delivers better public policy advice may well require conditions of employment which if present in the private sector, would be regarded as anti-competitive. Seurity of tenure is but one example; others include the assessment of promotion and careerr advancement in the civil service being completely independent of plitical decision making and the assessment of pay and conditions for the public sictor also being independent of politics. (This is not to deny a role for the market; rather itt is to mitigate against a role for political interference in the independence of the public service.)

A similar argument concerning pay applies; to political office. To get talented individuals in a democracy to ofer themsellves for election, the rewards of political office must be at least conparable with those of the private sector. It is astounding how often the contrary view is expressed. It goes without saying that legislation must also ensure, to the extent that politicians' and public servants' private lives have nothing to do wth the performance of their public duties, that what is private remains private. The public does not have the right to know all, as recent events in the U.S. only too obviously' demonstrate. Such unnecessary 
prying only demeans public office and lessen the likelihood that the best people are attracted to be politicians andl public serunts. Private saintliness, no matter how desirable, is not a necessary ccondition forpublic office.

To guard against bureaucrattic sclerosis and opportunistic behaviour, it is essential that government be opeen and tranparent. The 'Good Society' will realise that it is necessary for the jpublic to hare access to official documents and decisions, quickly and relatively ffreely, excejt where access would compromise the political process. This is not to say thatall information should be available immediately (for example, Cabinet records). The efficiency of the Australian system of government requires polliticians andpolitical parties to be able to debate issues freely and frankly without these debate: being used to compromise them at a later date. So internal debates sthould remain internal. What is being discussed here are decisions and official doctuments which emerge at the end of this process. But, again, judgement is involvedl. ${ }^{5}$ Freedom of information (and virtually all of it!) and appropriate legislation and procedure to ensure it are vital. Again, an independent public sector is essenitial, but onewith adequate checks and balances to ensure complete transparency and not obfiscation. Transparency and checks and balances will also help in the fïight againstinefficient empire building.

\section{Conclusion}

This paper has just scratched the surface of hov a more complete understanding of the complexity and diversity of ecconomics wold very quickly show that the neoliberal economic policy agenda is seriously deficient and selective. Modern economics is far richer than the narrow, deologically driven neo-liberalism agenda. While recognising fully the power of markets to efficiently allocate resources and improve economic welfare, the complete practitioner of modern economics will also recognise thatt market faiure, macroeconomic equilibrium at less than full employment and inequality are integral parts of market capitalism, and that market failure, business cycles anc inequality require an active and judicious role for the state.

\section{References}

Argy, F. (1998), Australia at the Ciross Roads: Radical Free Market or Progressive Liberalism, Allen \& Unwin, Sydney.

Bator, F. (1957), 'The Simple Analyttics of Welfae Maximization', American Economic Review 47(1):22-59.

Card, D. and A. Krueger (1994), 'Miinimum Wagts and Employment: A Case Study of the Fast-Food Industry in New Jersey and Pennylvania', American Economic Review 44(4):772-93.

5 I would like to thank Hugh Strettom for making ne think more clearly about this issue. 
Dixit, A. and A. Kyle (1985), 'The Uie of Protection and Subsidies for Entry Promotion and Deterrence', American Economic Review 75(1):139-52.

Galbraith, J. (1958), The Affluent Socitty, Penguin Books, Harmondsworth, Middlesex.

Henderson, D. (1995), 'The Revival of Economic Liberalism: Australia in an International Perspective', Australian Economic Review 28(1):59-85.

Industry Commission (1995), The Growth and Revenue Implications of Hilmer and Related Reforms, AGPS, Canberra.

Kenyon, P. (1998), Comments on Borland, J. and S. Kennedy, 'Dimensions, Structure and History of Australian Unemployment', pp. 100-108 in Debelle, G. and J. Borland (eds), Unemployment and the Australian Lalour Market, Reserve Bank of Australia, Sydney.

Krugman, P. (1987), 'Is free trade passé?', Journal of Economic Perspectives 1(2):131-46.

Krugman, P. (ed.) (1988), Strategic Trade and the New International Economics, MIT Press, Cambridge, MA.

Krugman, P. (1996), Pop Internationdism, MIT Press, Cambridge, MA.

Krugman, P. (1998), 'Is the Economic Crisis a Crisis for Economics? Or, where is macroeconomics when we need it?' Slate On-Line Journal, 12 November (http://www.slate.com/Dismal/98-11-(2/Dismal.asp\#note2).

Krugman, P. (1999), The Return of Depression Economics, Allen Lane The Penguin Press, Harmondsworth, Middlesex.

Lewis, P. and K. Norris (1997), 'Recent Changes in Economics Enrolments', Economic Papers 16(1):1-14.

Pusey, M. (1991), Economic Rationalism in Canberra: A Nation Building State Changes its Mind, Cambridge University Press. Cambridge.

Quiggin, J. (1997) 'Estimating the Benefits of Hilmer and Related Reforms', Australian Economic Review 30(3):256-272.

I would like to thank Robert Albon for his extensive comments on an earlier draft. 